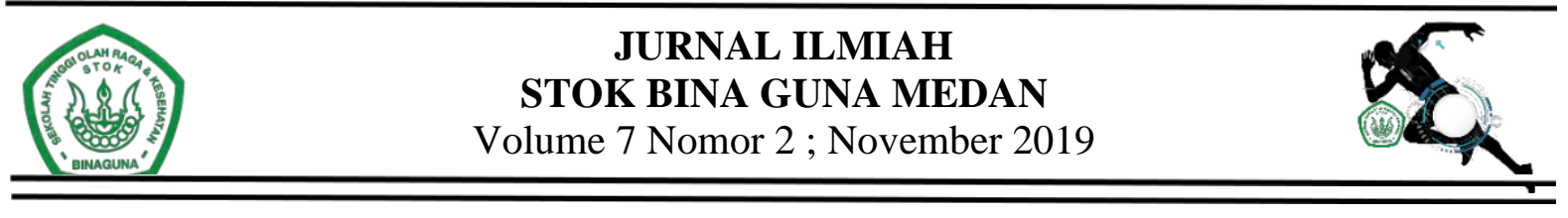

\title{
UPAYA MENINGKATKAN HASIL BELAJAR SMASH DALAM PERMAINAN BOLA VOLI MELALUI GAYA MENGAJAR INKLUSI
}

\section{EFFORTS TO IMPROVE SMASH LEARNING OUTCOMES IN VOLYBALL GAMES THROUGH INCLUSIVE TEACHING STYLE}

\author{
Fajar Siddik Siregar ${ }^{1}$, M. Syaleh ${ }^{2}$ \\ ${ }^{1,2}$ Sekolah Tinggi Olahraga dan Kesehatan Bina Guna \\ Jl. Aluminium Raya No. 77 Tanjung Mulia, 20241, Indonesia \\ Email : fajarsiregar1988@gmail.com
}

\begin{abstract}
ABSTRAK
Penelitian ini bertujuan untuk mengetahui peningkatan hasil belajar Smash dalam permainan bola voli melalui gaya mengajar inklusi pada siswa X SMA Muhammadiyah 2 MedanTahun ajaran 2015/2016. Subjek dalam penelitian ini adalah kelas X dengan jumlah siswa sebanyak 32 orang siswa yang akan diberikan tindakan berupa pengajaran melalui gaya mengajar inklusi terhadap hasil belajar Smash dalam permainan bola voli. Penelitian ini menggunakan metode penelitian tindakan kelas, yang terdiri dari dua siklus. Sebelum dilakukan tindakan pada siklus I peneliti memberi tes awal untuk mengetahui letak kesulitan pada pelajaran Smash bola voli, kemudian dilakukan pembelajaran menggunakan gaya mengajar Inklusi dan diakhiri dengan pemberian tes siklus I dan tes siklus II dengan instrumen penelitian lembaran pengamatan tes hasil belajar Smash bola voli dengan menggunakan lembar portofolio. Setelah data terkumpul dan dilakukan analisis maka diperoleh hasil analisisnya : (1) dari data hasil tes belajar Siklus I diperoleh 12 orang (37,5\%) yang telah mencapai tingkat ketuntasan belajar, sedangkan 20 orang $(62,5 \%)$ belum mencapai tingkat ketuntasan belajar. (2) dari tes hasil belajar Siklus II diperoleh 17 orang $(84,37 \%)$ yang telah mencapai tingkat ketuntasan belajar, sedangkan 15 orang $(15,63 \%)$ belum mencapai tingkat ketuntasan belajar,. Dalam hal ini dapat dilihat bahwa terjadi peningkatan nilai rata-rata hasil belajar siswa dari siklus I ke siklus II yaitu peningkatan ketuntasan klasikalnya sebesar $25 \%$. Berdasarkan hasil analisis data dapat dikatakan bahwa melalui gaya mengajar inklusi meningkatkan hasil belajar Smash dalam permainan bola voli pada siswa-siswi SMA Muhammadiyah 2 MedanTahun ajaran 2015/2016.
\end{abstract}

\section{Kata kunci: Hasil Belajar Smash, Gaya mengajar Inklusi}

\section{ABSTRACT}

This study aims to determine the improvement of Smash learning outcomes in volleyball games through inclusive teaching styles for students of X SMA Muhammadiyah 2 Medan for the 2015/2016 academic year. The subjects in this study were class X with a total of 32 students who would be given action in the form of teaching through inclusive teaching styles on the learning outcomes of Smash in volleyball games. This research uses classroom action research method, which consists of two cycles. Before taking action in the first cycle, the researcher gave an initial test to determine the location of the difficulties in the volleyball smash lesson, then learning was carried out using the inclusive teaching style and ended with giving the first cycle test and second cycle test with research instruments. using a portfolio 
sheet. After the data is collected and analyzed, the results of the analysis are obtained: (1) from the data from the learning test results in Cycle I, 12 people (37.5\%) have reached the learning mastery level, while 20 people (62.5\%) have not reached the mastery level study. (2) from the test of learning outcomes in Cycle II, 17 people (84.37\%) have reached the learning mastery level, while 15 people (15.63\%) have not reached the learning mastery level. In this case, it can be seen that there is an increase in the average value of student learning outcomes from cycle I to cycle II, namely an increase in classical completeness by $25 \%$. Based on the results of data analysis, it can be said that through inclusive teaching style improves learning outcomes of Smash in volleyball games for private high school students, Dharma Karya College, 2015/2016 academic year.

\section{Keywords: Smash Learning Outcomes, Inclusive Teaching Style}

\section{PENDAHULUAN}

Dalam dunia kehidupan, pendidikan memegang peranan penting karena pendidikan merupakan wahana untuk meningkatkan dan mengembangkan kualitas sumber daya manusia (SDM). Sejalan perkembangan dunia pendidikan yang semakin pesat menuntut lembaga pendidikan untuk dapat menyesuaikan dengan perkembangan ilmu pengetahuan. banyak perhatian khusus diarahkan kepada perkembangan dan kemajuan pendidikan guna meningkatkan mutu dan kualitas pendidikan. Salah satu cara yang dilakukan untuk meningkatkan kualitas pendidikan adalah dengan pembaharuan sistem belajar yang kurang baik.

Proses belajar mengajar merupakan suatu aktivitas yang bertujuan untuk mengarahkan peserta didik pada perubahan tingkah laku yang diinginkan. Peningkatan mutu pembelajaran tentunya dapat kita lihat dari bagaiman cara guru dalam membawakan pembelajaran pada peserta didiknya. Hal tersebut bisa di pahami karena mengarahkan peserta didik menuju perubahan yang diinginkan merupakan suatu pekerjaan yang berat. Sekolah sebagai tempat atau wadah pendidikan formal yang mempunyai tugas untuk menyelenggarakan pembinaan mentalspritual, intelektual, dan khususnya pembinaan kualitas fisik peserta didik melalui mata pelajaran pendidikan jasmani (Sanur, S. (2016).
Seiring dengan uraian diatas, penggunaan gaya mengajar dalam kegiatan proses belajar mengajar merupakan salah satu cara pendekatan yang dilakukan untuk bisa kemudian diharapkan meningkatkan hasil belajar peserta didik.

Dalam hal ini, metode mengajar dalam pemberian latihan maupun proses pelaksanaan pembelajaran sangat perlu diperhatikan. Kegagalan dari usaha pencapaian tujuan yang diharapkan bisa saja terjadi karena metode yang digunakan guru dalam menyampaikan pembelajaran tidak memberikan kesempatan kepada siswa untuk melakukan gerakan dengan leluasa.

Dalam mencapai tujuan pembelajaran, diharapkan tentunya sebagai seorang guru harus mengusai metode pembelajaran. Karena apabila ingin mencapai hasil pembelajaran yang baik, sebagai seorang guru harus memiliki kemampuan akademik yang lebih baik dalam membawakan matapelajarannya terkhusus pendidikan jasmani. Sejalan dengan itu, penggunaan metode mengajar sebagai alat bantu pelaksanaan mengajar merupakan salah satu bentuk pendekatan yang bisa diharapkan dalam meningkatkan hasil belajar .

Penggunaan gaya mengajar itu sendiri bukanlah suatu hal yang baru dalam dunia pendidikan. Pada umumnya guru sudah menerapkan di sekolah. Hanya saja, untuk pendidikan jasmani gaya yang cenderung digunakan adalah gaya komando. 
Banyak metode atau gaya mengajar yang dapat digunakan dalam pembelajaran penjas (Syiroj, A., Sunarno, A., \& Dewi, R., 2017). Metode yang digunakan sebaiknya disesuaikan dengan materi pelajaran yang akan disampaikan (Haris, A., \& Ghazali, M. I., 2016). Beberapa metode mengajar dapat diterapkan selama pembelajaran berlangsung tergantung dari keadaan kelas atau siswa (Parlindungan, D. P., 2018).

Permainan bola voli merupakan satu bentuk olahraga permainan yang ada dalam kurikulum pendidikan pendidikan jasmani sekolah (Rifán, M., \& Tengah, P. S., 2013). Teknik dasar permainan bola voli yaitu teknik passing atas, servis, passing bawah, smash, blocking (Iskandar, M. I., 2018).

Hasil observasi yang dilakukan peneliti di sekolah SMA Muhammadiyah 2 Medanpada bulan maret pemahaman dan kemampuan dalam permainan bola voli para peserta didik di sekolah masih kurang menguasai, khususnya kemampuan dasar untuk melakukan smash kurang menguasai teknik tersebut. Pada saat siswa melakukan smash mereka tidak memakai awalan dengan melangkahkan kaki serta mengayunkan kedua tangan tetapi langsung melompat sehingga timing bola dengan lompatan tidak seirama.

Hal ini merupakan hal yang sangat sulit dilakukan siswa karena mereka belum dapat mengatur kapan dan dimana mereka harus melompat sehingga posisi tubuh mereka berada tepat di belakang bola dan memukul bola tepat di depan atas kepala melainkan mereka memukul bola ketika bola berada tepat di atas kepala sehingga mereka tidak bisa melihat bola dan melihat arah bola yang di tuju pada saat bersamaan. Hal seperti di atas juga bisa di karenakan mereka melompat terlalu dekat dengan net yang membuat mereka berada di bawah bola dan pada waktu mendarat, tangan yang di gunakan untuk memukul bola akan menyentuh net. Pada intinya para siswa sangat kesulitan dan belum dapat melaksanakan gerakan smash dalam permainan bola voli dengan teknik yang benar.

Sedangkan menurut Hamalik (2001:27) belajar adalah "modifikasi atau memperteguh kelakuan melalui pengalaman". Menurut pengertian ini, belajar merupakan suatu proses, sustu kegiatan dan bukan suatu hasil atau tujuan. Belajar bukan hanya mengingat, akan tetapi lebih luas dari itu yakni mengalami, memang jika dilihat sangat banyak ahliahli yang telah mencoba menfasirkan arti dari belajar.

\section{METODE}

Penelitian ini dilaksanakan di lapangan Voli Sekolah SMA Muhammadiyah 2 Medan Tahun Ajaran 2015/ 2016". Penelitian ini dilakukan dalam dua siklus (Sitorus Pane, B., 2014), dimana setiap siklus berisikan tindakan berupa pelaksanaan pembelajaran dengan gaya mengajar Inklusi yang disesuaikan dengan materi pelajaran. Sebelum pelaksanaan Tindakan I dilakukan, peneliti terlebih dahulu melakukan tes awal untuk melihat sejauh mana pemahaman siswa akan smash bola voli. Hal ini diperlukan sebagai informasi awal bagi peneliti untuk dapat memberikan pemecahan masalah dan kendala yang dihadapi siswa (Prayoga, A. S., 2016) dalam smash bola voli pada pelajaran penjaskes (Kholik, A., 2018).

\section{HASIL DAN PEMBAHASAN}

Berdasarkan tabel deskripsi hasil tes awal smash di atas dapat dilihat bahwa hasil be lajar siswa dalam pembelajaran smash masih rendah. Dari 32 orang siswa yang benjadi subjek dalam penelitian ini, ternyata hanya 10 orang siswa $(31,25 \%)$ yang sudah memiliki ketuntasan belajar, sedangakan selebihnya yaitu 22 orang 
siswa $(68,75 \%)$ belum memiliki ketuntasan belajar.

Adapun deskripsi hasil data awal yang diproleh siswa dapat di lihat pada tabel berikut ini:

Tabel 1. Deskripsi data awal Smash Siswa

\begin{tabular}{ccccc}
\hline No & $\begin{array}{r}\text { Hasil } \\
\text { Tes }\end{array}$ & $\begin{array}{c}\text { Sumlah } \\
\text { Siswa }\end{array}$ & $\begin{array}{l}\text { Persentas } \\
\text { e }\end{array}$ & Ketrangan \\
\hline 1. & $\geq 65$ & 10 & $31,25 \%$ & Tuntas \\
\hline 2. & $\leq 65$ & 22 & $68,75 \%$ & $\begin{array}{l}\text { Tidak } \\
\text { Tuntas }\end{array}$ \\
\hline
\end{tabular}

Siklus I Berdasarkan hasil yang dicapai dalam proses pembelajaran dengan menggunakan gaya mengajar Inklusi pada kelas $\mathrm{X}$ SMA Muhammdiyah 2 Medanpermasalahan yang dialami siswa dalam mempelajari materi smash bola voli adalah siswa kurang bersemangat, siswa kurang mengerti pada saat melakukan sikap memainkan bola dalam smash bola voli, dan siswa terlihat canggung dengan gaya mengajar yang dipakai dalam pembelajaran.

Secara kelompok (klasikal), ketuntasan belajar dinyatakan telah tercapai jika sekurang- kurangnya $85 \%$ dari siswa yang ada dalam kelompok bersangkutan telah memenuhi kriteria ketuntasan minimal per individu sebesar $\geq$ 65\%.( Berdasarkan Kurikulum Sekolah).

Tabel 2.Deskripsi hasil belajar siklus I

\begin{tabular}{ccccc}
\hline No & $\begin{array}{c}\text { Hasil } \\
\text { Test }\end{array}$ & $\begin{array}{c}\text { Jumlah } \\
\text { siswa }\end{array}$ & $\begin{array}{c}\text { Perse } \\
\text { ntase }\end{array}$ & $\begin{array}{c}\text { Keteran } \\
\text { gan }\end{array}$ \\
\hline 1. & $<65$ & 12 & 37,5 & Tuntas \\
\hline 2. & $>65$ & 20 & $62,5 \%$ & $\begin{array}{l}\text { Tidak } \\
\text { Tuntas }\end{array}$
\end{tabular}

Dari data hasil tes belajar Siklus I diperoleh 12 orang $(37,5 \%)$ yang telah mencapai tingkat ketuntasan belajar, sedangkan 20 orang $(62,5 \%)$ belum mencapai tingkat ketuntasan belajar.

Tabel 3. Deskripsi Hasil Belajar Siklus II

\begin{tabular}{ccccc}
\hline No & $\begin{array}{c}\text { Hasil } \\
\text { Tes }\end{array}$ & $\begin{array}{c}\text { Jumlah } \\
\text { Siswa }\end{array}$ & Persentase & $\begin{array}{c}\text { Ketera } \\
\text { ngan }\end{array}$ \\
\hline 1. & Skor & 17 & $84,37 \%$ & Tidak \\
& $<64$ & & & Tuntas \\
\hline 2. & Skor & 15 & $15,63 \%$ & Tuntas \\
& $>65$ & & & \\
& & & & \\
& Dari tes hasil belajar Siklus II
\end{tabular}
diperoleh 17 orang $(84,37 \%)$ yang telah mencapai tingkat ketuntasan belajar, sedangkan 15 orang $(15,63 \%)$ belum mencapai tingkat ketuntasan belajar

Setelah proses observasi II ilakukan, selanjutnya dilakukan kembali analisis dari data hasil belajar II yang ditetapkan. Dari hasil belajar siklus II yang didapat kemudian kembali reduksi dan dipaparkan bentuk tabel dengan menggunakan rumus yang sama seperti siklus I.

Adapun kesulitan -kesulitan yang dialami siswa dalam pembelajaran dengan menggunakan gaya mengajar inklusi antara lain adalah: a) Siswa kurang baik melakukan gerakan teknik smash dalam permainan bola voli. Untuk mengatasinya guru mengevaluasi kesalahan siswa dalam melakukan gerakan dan memberikan motivasi kepada siswa, b) Siswa masih terlihat canggung dengan gaya mengajar inklusi yang dipakai dalam pembelajaran. Untuk mengatasi guru menjelaskan gaya inklusi dan tujuan pembelajaran.

Penyelenggaraan pendidikan jasmani di sekolah selama ini berorientasi pada suatu titik pusat yaitu guru(Asmajaya, D. (2016). Kenyataan ini dapat dilihat melalui pengamatan yang dilakukan penulis di lapangan bahwa gurulah yang memiliki kuasa penuh dalam proses belajar mengajar tanpa mempertimbangkan aspek 
perkembangan motorik peserta didik. Sehingga metode yang diajarkan tidak berjalan dengan baik (Raswin, R., \& Aulia, R., 2015).

\section{KESIMPULAN}

Berdasarkan hasil analisis data dan pembahasan, maka hasil penelitian dapat disimpulkan sebagai berikut: Penerapan gaya mengajar dalam pembelajaran smash bola voli dapat dijadikan alternative untuk meningkatkan kemampuan Hasil Belajar smash bola voli bagi siswa kelas SMA Muhammadiyah 2 Medan.

\section{DAFTAR PUSTAKA}

Asmajaya, D. (2016). Upaya Meningkatan Hasil Belajar Servis Atas Bola Voli Dengan Menggunakan Metode Drill Pada Siswa Kelas Vii Smp Negeri 3 Percut Sei Tuan Tahun Ajaran 2016/2017. Jurnal Pedagogik Olahraga, 2(2), 20-29.

Haris, A., \& Ghazali, M. I. (2016). Implementation of teaching physical education teachers apply mutual adaptation approach in junior high school in Makassar, Indonesia. International Journal of Academic Research and Development, 1(5), 77-84.

Hamalik, Oemar. (2001). Proses Belajar Mengajar. Jakarta: Bumi Aksara.

Iskandar, M. I. (2018). Upaya Meningkatkan Hasil Belajar Passing Bawah Bola Voli Mini Dengan Menggunakan Pendekatan Pembelajaran Drill Pada Siswa Kelas V Sd Negeri 1 Jungke Karanganyar Tahun Ajaran 2017/2018. Jurnal Ilmiah Spirit, 18(2).

Kholik, A. (2018).

BELAJAR SERVIS BAWAH BOLA VOLLEY MELALUI MODEL PEMBELAJARAN
RESIPROKAL BAGI PESERTA

DIDIK KELAS IV SDN 2

KARANGKEMOJING. Dwija

Inspira: Jurnal Pendidikan Multi

Perspektif, 1(1), 23-32.

Parlindungan, D. P. (2018). MANFAAT MODEL LATIHAN OFFENCE PADA PERMAINAN BOLAVOLI. Halaman Olahraga Nusantara (Jurnal Ilmu Keolahragaan), 1(2), 229-236.

Prayoga, A. S. (2016). Upaya Meningkatkan Hasil Belajar Servis Bawah Bola Voli Melalui Penggunaan Modifikasi Bola. Jurnal Sportif, 2(1), 1-12.

Raswin, R., \& Aulia, R. (2015). Upaya Peningkatan Hasil Belajar Bola Voli Mini Melalui Pembelajaran Menggunakan Media Bola Karet. Jurnal Ilmu Keolahragaan, 14(1), 68-77.

Rifán, M., \& Tengah, P. S. (2013). Pengaruh Latihan Skipping Terhadap Loncatan Vertikal Smash Dalam Permainan Bola Voli Pada Siswa Kelas X SMA Negeri 4 Palu. Tadulako Journal Sport Sciences And Physical Education, 1(1), 1-14.

Sanur, S. (2016). Upaya Meningkatkan Hasil Belajar Servis Atas Permainan Bola Voli Dengan Pendekatan Bermain Pada Siswa Kelas VI SDN Batokerbuy 2 Tahun Ajaran 2015/2016. JOURNAL $O F$ SPORTIF, 2(1), 93-100.

Sitorus Pane, B. (2014). UPAYA PENINGKATAN

PEMBELAJARAN PASSING BAWAH BOLA VOLI MELALUI PEMBERIAN GAYA MENGAJAR INKLUSI PADA MAHASISWA JURUSAN PKO REG. B ANGKATAN 2010 FIK-UNIMED 2012. Jurnal Ilmu Keolahragaan, 13(01), 66-78. 
Syiroj, A., Sunarno, A., \& Dewi, R. (2017). Perbedaan Gaya Mengajar Dan Motor Educability Terhadap Hasil Belajar Passing Bawah Bola Voli Pada Siswa Kelas Xi Man Rantauprapat. Jurnal Pedagogik Olahraga, 3(1), 15-31. 